\title{
Penerapan Model Pembelajaran Inkuiri Terbimbing untuk Meningkatkan Sikap Ilmiah dan Prestasi Belajar Kimia Siswa
}

\author{
Ira Maya Tri Murningsih ${ }^{1} *$, Mohammad Masykuri ${ }^{2}$ Bakti Mulyani $^{3}$ \\ ${ }^{123}$ Program Studi Pendidikan Kimia, Universitas Sebelas Maret. Jalan Ir. Sutami No.36 A Surakarta \\ 57126, Jawa Tengah, Indonesia \\ * Korespondensi Penulis. Email: mayyaira25@gmail.com, Telp: (0271) 669376
}

\begin{abstract}
Abstrak
Penelitian ini bertujuan untuk meningkatkan sikap ilmiah dan prestasi belajar siswa menggunakan model pembelajaran Inkuiri Terbimbing pada materi pokok kelarutan dan hasil kali kelarutan kelas XI MIPA 3 SMA Negeri 5 Surakarta tahun ajaran 2015/2016. Penelitian ini merupakan Penelitian Tindakan Kelas yang terdiri dari dua siklus. Subjek penelitian adalah siswa kelas XI MIPA 3 SMA Negeri 5 Surakarta tahun pelajaran 2015/2016 yang terdiri dari 30 siswa. Objek penelitian adalah sikap ilmiah siswa dan prestasi belajar kimia siswa. Sumber data adalah siswa dan guru. Teknik pengumpulan data melalui metode observasi, wawancara, dokumen/arsip, angket dan tes. Teknik analisis yang digunakan adalah analisis deskriptif. Berdasarkan hasil penelitian didapatkan bahwa pencapaian sikap ilmiah pada siklus I sebesar 60\% dan pada siklus II menjadi 93\%. Peningkatan prestasi belajar aspek pengetahuan pada siklus I diperoleh ketuntasan belajar sebesar 63\% dan pada siklus II menjadi 93\%. Pada prestasi belajar siswa aspek sikap dan aspek keterampilan ketercapaian ketuntasan siswa pada siklus I sebesar 100\%,sehingga tidak dilanjutkan ke siklus II karena semua indikator sudah terpenuhi.
\end{abstract}

Kata Kunci: inkuiri terbimbing, kelarutan dan hasil kali kelarutan, penelitian tindakan kelas, prestasi belajar, sikap ilmiah

\section{Implementation of Guided Inquiry Model to Improve Behaviour Scientific and Student's Chemistry Learning Achievement}

\begin{abstract}
The aims of the research were to improve scientific behaviour and student's learning achievement by implementing guided inquiry model on primary material of solubility and solubility product at XI MIPA 3 students of SMA Negeri 5 Surakarta in the academic year of 2015/2016. This research was a Classroom Action Research (CAR) which was held in two cycles. The research subject was the students of class XI MIPA 3 at SMA Negeri 5 Surakarta in the academic year of 2015/2016 consisted of 30 students. The object of research was the behavior scientific and student's chemistry learning achievement. Source of data were students and teacher. Data was obtained through observations, interviews, document, questionnaires, and test. The data were analyzed using technique of qualitative descriptive analysis. The result of the research can be seen from cycle I the percentage of student's scientific behaviour was $60 \%$ and increased to $93 \%$ in the cycle II. Improved learning achievement on knowledge aspect from $63 \%$ in cycle I to $93 \%$ in cycle II. Attitude aspect and skill aspect, the improvement has reached $100 \%$, so it was not continued to cycle 2 since all off the indicators have been accomplished before.
\end{abstract}

Keywords: guided inquiry, solubility and solubility product, classroom action research, learning achievement, scientific behaviour

How to Cite: Murningsih, I., Masykuri, M., \& Mulyani, B. (2016). Penerapan model pembelajaran inkuiri terbimbing untuk meningkatkan sikap ilmiah dan prestasi belajar kimia siswa. Jurnal Inovasi Pendidikan IPA, 2(2), 177-189. doi:http://dx.doi.org/10.21831/jipi.v2i2.11196

Permalink/DOI: http://dx.doi.org/10.21831/jipi.v2i2.11196 
Jurnal Inovasi Pendidikan IPA, 2 (2), 2016 - 178

Ira Maya Tri Murningsih, Mohammad Masykuri, Bakti Mulyani

\section{PENDAHULUAN}

Umumnya, pendidikan merupakan sarana menumbuhkan potensi/bakat individu dalam bermasyarakat dan elemen penting untuk menciptakan sumber daya manusia yang berkualitas, cerdas, terbuka, mampu bersaing dan meningkatkan kesejahteraan rakyat Indonesia. Terealisasinya pendidikan yang berkualitas, pemerintah perlu melakukan suatu perubahan terhadap sistem pendidikan yang berkesinambungan. Salah satu upaya yang dilakukan adalah memperbaiki sistem kurikulum. Proses pembaruan dan penyempurnaan sistem pendidikan menghasilkan suatu kurikulum baru yang dipandang lebih efektif dalam proses pembelajaran.

Sesuai Permendikbud Nomor 69 Tahun 2013, kurikulum 2013 merupakan langkah lanjutan pengembangan Kurikulum Berbasis Kompetensi yang telah dirintis pada tahun 2004 dan KTSP 2006 yang mencakup kompetensi pengetahuan, sikap, dan keterampilan secara terpadu. Karakteristik kurikulum 2013 dengan menggunakan pendekatan saintifik. Selain menggunakan pendekatan saintifik, kurikulum 2013 juga mengacu pada pendidikan berkarakter. Peserta didik diharapkan tidak hanya unggul dalam kompetensi pengetahuan, tetapi juga unggul dalam sikap dan keterampilan dalam bekerja.

Pada kurikulum 2013 diharapkan dapat menghasilkan insan Indonesia yang produktif, kreatif, afektif dan inovatif melalui penguatan sikap, keterampilan, dan pengetahuan yang terintegrasi. Kurikulum 2013 menerapkan perubahan pola pendidikan dari orientasi terhadap hasil dan materi kependidikan sebagai proses, melalui pendekatan tematik integrative dengan Contextual Teaching and Learning (CTL). Oleh karena itu, pembelajaran harus sebanyak mungkin melibatkan peserta didik. Berdasarkan Permendikbud Nomor 65 Tahun 2013 tentang Standar Proses, model pembelajaran yang diutamakan dalam implementasi kurikulum 2013 adalah inkuiri, discovery, PBL (project based learning), berbasis proyek dan berbasis pemecahan masalah.

Menurut Permendikbud Nomor 69 Tahun 2013, kimia adalah salah satu mata pelajaran wajib bagi siswa SMA jurusan ilmu pengetahuan Alam. Perlunya mempelajari kimia karena berhubungan dengan kehidupan sehari-hari. Peranan ilmu kimia tidak hanya pada ilmu-ilmu murni saja melainkan juga pada ilmu terapan. Pada umumnya, kimia merupakan salah satu pelajaran yang dianggap sulit oleh beberapa siswa. Berdasarkan hasil wawancara yang telah dilakukan dengan guru kimia SMA Negeri 5 Surakarta, diketahui salah satu materi yang dianggap sulit oleh siswa pada kelas XI MIPA semester genap adalah kelarutan dan hasil kali kelarutan. Materi Kelarutan dan hasil kelarutan merupakan materi pelajaran kimia yang menuntut siswa untuk dapat menggabungkan antara penguasaan konsep kimia dan mengaplikasikannya dalam perhitungan kimia. Apabila siswa kurang menguasai konsep yang ada, maka siswa akan mengalami kesulitan untuk menyelesaikan soal-soal yang berkaitan dengan konsep materi kelarutan dan hasil kali kelarutan.

Ditunjukkan dari nilai ulangan harian kimia semester genap tahun pelajaran 2014/2015 pada materi kelarutan dan hasil kali kelarutan, diperoleh nilai ketuntasan siswa yakni sebanyak 86 siswa dari 163 siswa kelas XI MIPA atau 53\% dengan Kriteria Ketuntasan Minimal (KKM) sebesar 75. Hal ini menurut guru kimia kelas XI MIPA SMA Negeri 5 Surakarta, ketuntasan materi tersebut masih rendah sehingga perlu diperbaiki dan ditingkatkan.

Melalui Nilai Ulangan Akhir Semester (UAS) ganjil siswa kelas XI MIPA SMA Negeri 5 Surakarta tahun pelajaran 2015/2016, Dapat dilihat dari Tabel 1.

Tabel 1. Nilai rata-rata Ulangan Akhir Semester (UAS) Semester Ganjil Siswa Kelas XI MIPA SMAN 5 Surakarta Tahun Ajaran 2015/2016.

\begin{tabular}{cc}
\hline Kelas & Nilai rata-rata \\
\hline XI MIPA 1 & 66 \\
XI MIPA 2 & 68 \\
XI MIPA 3 & 61 \\
XI MIPA 4 & 65 \\
XI MIPA 5 & 68 \\
\hline
\end{tabular}

Diketahui nilai rata-rata UAS paling rendah terletak pada kelas XI MIPA 3. Guru juga menyatakan bahwa dalam proses pembelajaran kelas XI MIPA 3 adalah kelas yang memiliki prestasi belajar rendah jika dibandingkan dengan kelas XI MIPA yang lain.

Keberhasilan proses pembelajaran selain didasarkan pada faktor eksternal juga memperhatikan faktor internal salah satunya adalah sikap ilmiah siswa. Wawancara lanjutan dengan guru kimia yang mengampu kelas XI MIPA 3 mengemukakan sikap ilmiah dalam pembelajaran kimia di SMA Negeri 5 Surakarta cenderung kurang terutama pada kelas XI MIPA 3. Pernyataan dari guru kimia tersebut juga didukung dengan observasi yang dilakukan oleh 
Jurnal Inovasi Pendidikan IPA, 2 (2), 2016 - 179

Ira Maya Tri Murningsih, Mohammad Masykuri, Bakti Mulyani

peneliti pada saat prasiklus di SMA Negeri 5 Surakarta.

Hasil observasi yang dilakukan, siswa kelas XI MIPA 3 SMA Negeri 5 Surakarta cenderung kurang berani mengungkapkan pendapat ketika berdiskusi maupun dalam kegiatan presentasi. Ketika kegiatan belajar-mengajar, guru memberikan kesempatan kepada siswa untuk menjawab pertanyaan dan mengerjakan soal di depan, siswa cenderung pasif dan takut. Pada saat proses pembelajaran di kelas XI MIPA 3 terdapat siswa yang kurang tertarik dalam mengikuti pelajaran kimia, beberapa ada yang berbicara sendiri dengan teman sebangkunya. Dalam berdiskusi kelompok beberapa siswa bersikap pasif, hanya satu atau dua orang saja yang mengemukakan pendapat dan yang lainnya mengikut saja. Hal ini membuktikan bahwa sikap berpikir kritis, rasa ingin tahu, tekun, teliti, menyampaikan gagasan yang merupakan bagian dari karakteristik sikap ilmiah (Fatonah \& Prasetyo, 2014) pada siswa XI MIPA 3 dinilai belum cukup baik.

Berdasarkan uraian tersebut, maka dapat disimpulkan bahwa permasalahan pembelajaran yang terjadi di kelas XI MIPA 3 adalah sikap ilmiah yang kurang dan rendahnya prestasi belajar siswa. Selain dilihat dari hasil observasi selama PPL dan prasiklus serta wawancara terhadap guru kimia yang mengampu kelas tersebut, kurangnya sikap ilmiah siswa juga didukung dari hasil tes prasiklus yang menunjukkan sebanyak 37\% siswa berkategori sikap ilmiah tinggi, 63\% siswa berkategori sikap ilmiah sedang, dan 0\% siswa berkategori kemampuan sikap ilmiah rendah.

Sikap ilmiah merupakan sikap yang dominan dimiliki siswa dalam pembelajaran sains dan apalagi sangat diperlukan untuk mendukung keberhasilan kurikulum 2013. Definisi sikap ilmiah adalah kecenderungan individu untuk bertindak atau berperilaku dalam memecahkan masalah sistematis melalui langkah-langkah ilmiah (Baharudin, 1982). Sikap ilmiah diharapkan dapat menjadikan siswa yang aktif dan kreatif dalam pembelajaran. Umumnya siswa yang memiliki sikap ilmiah yang tinggi memiliki prestasi belajar yang tinggi pula. Hal ini didukung dari penelitian Pertiwi, Eny \& Husna (2013) bahwa sikap ilmiah mengalami peningkatan, dengan rata-rata persentase peningkatannya sebesar $57 \%$ pada siklus I dan $74 \%$ pada siklus II. Pertiwi, Eny \& Husna mengungkapkan bahwa sikap ilmiah siswa yang meningkat juga diiringi dengan meningkatnya prestasi belajar siswa.

Dari uraian permasalahan tersebut, maka perlu alternatif meningkatkan sikap ilmiah dan prestasi belajar siswa kelas XI MIPA 3 SMA Negeri 5 Surakarta. Tindak lanjut yang diperlukan dalam memecahkan masalah tersebut maka perlu dilakukan Penelitian Tindakan Kelas (PTK) atau Classroom Action Rasearch (CAR) yang bertujuan memperbaiki kualitas proses pembelajaran (Suyadi, 2012). Menurut Kasbolah (2001) untuk meningkatkan kualitas pembelajaran di sekolah, relevansi pendidikan, mutu hasil pendidikan serta efisiensi pengelolaan pendidikan dapat dilaksanakan melalui PTK. Tujuan PTK menurut Basrowi \& Suwandi (2008) adalah meningkatkan atau memperbaiki proses pembelajaran di kelas, meningkatkan relevansi pendidikan, meningkatkan mutu pendidikan, dan meningkatkan efisiensi pendidikan. Dalam penelitian tindakan kelas, guru dan peneliti mengamati, menganalisis proses pembelajaran dan melakukan penelitian terhadap siswa dilihat dari segi aspek interaksi dalam kegiatan belajar-mengajar di kelas, sehingga pendidik dapat memperbaiki proses pembelajaran agar menjadi lebih efektif. Peningkatan ataupun perbaikan terhadap hasil belajar siswa tidak boleh bersifat memaksa, melainkan guru harus memikirkan dan membuat perencanaan secara saksama dalam meningkatkan kesempatan belajar bagi siswanya serta memperbaiki kualitas mengajar-nya (Daryanto \& Rahardjo, 2012).

Penentukan berhasil-tidaknya kegiatan belajar-mengajar, guru diharuskan lebih kreatif dalam merancang strategi/model pembelajaran agar tercipta suasana yang menyenangkan, menantang, mudah dipahami dan membangun motivasi belajar siswa. Model pembelajaran yang dipilih guru merupakan salah satu faktor eksternal yang menunjang keberhasilan siswa. Selain itu diharapkan siswa akan lebih tertarik untuk mempelajari materi kimia khususnya pada materi pokok kelarutan dan hasil kali kelarutan, sehingga dapat membantu siswa dalam memahami materi. Berbagai model pembelajaran dalam dunia pendidikan diciptakan untuk membantu terciptanya suasana belajar yang lebih mengedepankan keikutsertaan siswa dalam proses belajar.

Salah satu model pembelajaran yang sesuai dengan kurikulum 2013 adalah model pembelajaran Inkuiri. Model pembelajaran inkuiri merupakan suatu rangkaian kegiatan belajar yang melibatkan secara maksimal selu- 
ruh kemampuan siswa untuk mencari dan menyelidiki secara sistematis, kritis, logis, analitis sehingga mereka dapat merumuskan sendiri penemuannya dengan penuh percaya diri (Gulo, 2002). Menurut Mulyasa (2007) mengatakan bahwa tujuan model pembelajaran inkuiri adalah meningkatkan kemampuan berpikir, bekerja dan bersikap ilmiah serta berkomunikasi sebagai salah satu aspek penting kecakapan hidup.

Menurut Vlassi \& Karaliota (2013) pada penelitiannya yang dilakukan di sekolah menengah Yunani menyebutkan bahwa penggunaan model pembelajaran inkuiri terbimbing lebih efektif jika dibandingkan dengan model konvensional.

Berdasarkan hasil penelitian yang dilakukan oleh Villagonzalo (2014) menunjukkan bahwa penerapan model inkuiri terbimbing dapat meningkatkan tingkat kerja siswa dan prestasi akademik siswa. Menurut Gladys Jack (2013) dalam jurnal penelitiannya, mengemukakan bahwa model pembelajaran inkuiri terbimbing sangat efektif jika digunakan dalam pembelajaran kimia dengan pemahaman konsep dan penerapan hitungan yang sering dianggap siswa sulit, seperti materi kelarutan dan hasil kali kelarutan. Materi tersebut tidak hanya berisi materi yang bersifat teoritis saja tapi juga materi hitungan yang cukup rumit. Pernyataan tersebut diperkuat dengan penelitian Utami, Dasna, \& Sulistina (2013), menyimpulkan bahwa pelaksanaan pembelajaran dengan model inkuiri terbimbing yang berlangsung di kelas XI IPA 5 SMAN 8 Malang pada materi kelarutan dan hasil kali kelarutan memiliki rata-rata keterlaksanaan sebesar $97 \%$ dan termasuk dalam kategori sangat baik.

Model inkuiri terbimbing memberikan kesempatan kepada siswa untuk menemukan konsep atau informasi yang dibimbing oleh guru. Siswa tidak merumuskan masalah, sebagian perencanaannya dilakukan oleh guru. Dengan model pembelajaran inkuiri terbimbing mampu meningkatkan sikap ilmiah siswa karena model ini memberi keleluasaan siswa dalam berpikir kritis dan berpartisipasi aktif di kelas. Hal ini didukung dengan penelitian Dewi, Dantes \& Sadia (2013) dalam jurnal penelitiannya, mengemukakan bahwa model pembelajaran inkuiri terbimbing dapat meningkatan sikap ilmiah dan hasil belajar siswa. Berdasarkan latar belakang di atas, dalam mengatasi permasalahan yang ada pada kelas XI MIPA 3 SMA Negeri 5 Surakarta, peneliti perlu melakukan penelitian tindakan kelas untuk meningkatkan sikap ilmiah dan prestasi belajar siswa dengan menerapkan model pembelajaran Inkuiri Terbimbing pada materi kelarutan dan hasil kali kelarutan di kelas XI MIPA 3 SMA Negeri 5 Surakarta Tahun Pelajaran 2015/2016

\section{METODE}

Penelitian ini merupakan Penelitian Tindakan Kelas yang terdiri atas dua siklus. Setiap siklusnya terdapat empat tahapan yang terdiri dari perencanaan tindakan, pelaksanaan tindakan, observasi dan refleksi.

Waktu penelitian dimulai pada bulan Februari hingga Oktober 2016. Penelitian ini dilaksanakan di SMA Negeri 5 Surakarta berlokasi di Jalan Letjen Sutoyo No. 18, Banjarsari, Surakarta 57135.

Subjek penelitian yang dilakukan adalah siswa kelas XI MIPA 3 SMA Negeri 5 Surakarta tahun ajaran 2015/2016 yang berjumlah 30 siswa. Pemilihan subjek dalam penelitian ini didasarkan pada permasalahan yang teridentifikasi di kelas XI MIPA 3 saat observasi awal. Pra siklus dilakukan dengan wawancara terhadap guru kimia yang mengampu kelas XI MIPA 3. Pernyataan dari guru kimia tersebut dibuktikan dengan hasil observasi dan penyebaran angket. Hasil akhir yang didapatkan pada pra siklus yaitu sikap ilmiah dan prestasi belajar siswa di kelas tersebut rendah.

Prosedur penelitian ini meliputi (1) tahap persiapan, (2) tahap perencanaan, (3) tahap pelaksanaan tindakan, (4) tahap observasi, dan (5) tahap refleksi. Pada tahap refleksi peneliti mencoba mengatasi kekurangan yang terjadi akibat tindakan yang telah dilakukan. Keberhasilan maupun kegagalan dari hasil refleksi dalam pelaksanaan tindakan maka peneliti dengan guru mengadakan diskusi untuk mengambil kesepakatan menentukan tindakan perbaikan berikutnya (siklus II) dalam proses pembelajaran yang dilaksanakan oleh peneliti.

\section{Data, Instrumen, dan Teknik Pengumpulan Data}

Data yang dikumpulkan dalam penelitian tindakan kelas ini meliputi informasi mengenai keadaan siswa dlihat dari data kualitatif dan kuantitatif. Data kualitatif meliputi data pra siklus kompetensi sikap ilmiah yang berupa hasil observasi, angket penilaian diri siswa dan wawancara terhadap guru kelas, data hasil observasi dan angket penilaian diri kompetensi sikap, data hasil observasi kompetensi keterampilan, data hasil observasi dan angket penilaian 
Jurnal Inovasi Pendidikan IPA, 2 (2), 2016 - 181

Ira Maya Tri Murningsih, Mohammad Masykuri, Bakti Mulyani

diri sikap ilmiah, serta hasil wawancara pra siklus dan observasi awal. Sedangkan data kuantitatif yang dikumpulkan dalam penelitian ini meliputi penilaian prestasi belajar pada materi kelarutan dan hasil kali kelarutan kelas XI MIPA SMA Negeri 5 Surakarta tahun pelajaran 2014/2015. Ulangan Akhir Semester Ganjil (UAS) kelas XI MIPA SMA Negeri 5 Surakarta tahun pelajaran 2015/2016 dan penilaian prestasi belajar siswa materi pokok kelarutan dan hasil kali kelarutan kelas XI MIPA 3 SMA Negeri 5 Surakarta tahun pelajaran 2015/2016 yang berupa nilai tes pengetahuan, sikap dan keterampilan siswa terhadap pembelajaran baik pada siklus I dan siklus II.

Sumber data sebagai sasaran pengumpulan data dan penggalian permasalahan di kelas XI MIPA 3 serta informasi yang meliputi: (1) Informan, yaitu guru dan siswa, (2) Sumber data peristiwa, yakni lembar observasi sikap ilmiah, lembar observasi sikap dan lembar observasi keterampilan, (3) Dokumen/arsip yakni arsip nilai ketuntasan prestasi belajar materi pokok kelarutan dan hasil kali kelarutan kelas XI MIPA SMA Negeri 5 Surakarta tahun pelajaran 2014/2015, nilai Ulangan Akhir Semester Ganjil (UAS) kelas XI MIPA SMA Negeri 5 Surakarta Tahun Pelajaran 2015/2016, silabus dan Rencana Pelaksanaan Pembelajaran (RPP), nilai ketuntasan prestasi belajar materi pokok kelarutan dan hasil kelarutan kelas XI MIPA 3 SMA Negeri 5 Surakarta tahun pelajaran 2015/2016 siklus I dan siklus II, hasil penilaian sikap siklus I dan II, hasil penilaian keterampilan, dan hasil penilaian sikap ilmiah siklus I dan II.

Teknik pengumpulan data erat kaitannya dalam penelitian tindakan kelas. Perolehan data meliputi informasi tentang keadaan siswa dilihat dari aspek kualitatif dan kuantitatif seperti yang diuraikan tersebut. Teknik pengumpulan data yang dilakukan peneliti pada penelitian tindakan kelas dilakukan dengan dua teknik yakni tes dan non tes. Tingkat kemampuan prestasi belajar siswa aspek pengetahuan dapat diketahui dengan dilakukannya tes sesuai siklus yang ada. Tes dilakukan pada akhir siklus I dan siklus II sebab untuk mengetahui implikasi dari tindakan yang telah diberikan dalam kegiatan belajar mengajar terhadap penguasaan materi dan prestasi belajar siswa pada materi kelarutan dan hasil kali kelarutan. Instrumen soal disusun untuk mengetahui aspek pengetahuan siswa, sedangkan teknik non tes tidak terdapat jawaban yang benar maupun yang salah. Teknik tersebut terdiri dari wawancara, observasi, kajian dokumen dan angket.
Kualitas data hasil penelitian dipengaruhi valid atau tidaknya data yang bergantung pada instrumen pengumpulan data. Instrumen memenuhi dua persyaratan yaitu harus valid dan reliabel. Apabila instrumen tidak baik maka data yang diperoleh juga tidak benar sehingga kesimpulan yang didapatkan tidak sesuai kenyataan. Sedangkan sebaliknya, apabila instrumen baik maka data yang diperoleh benar dan kesimpulan sesuai kenyataan (Arikunto, 1992), sehingga sebelum digunakan dalam penelitian instrumen harus dilakukan uji validasi terlebih dahulu dengan validitas isi dan untuk tes pengetahuan dan angket penilaian diri ditryoutkan terlebih dahulu sebelum digunakan. Instrumen dibagi menjadi dua yaitu instrumen pembelajaran dan instrumen penilaian. Pada penelitian ini instrumen pembelajaran meliputi silabus, RPP dan soal diskusi, sedangkan instrumen penelitian meliputi tes pengeta-huan, angket sikap, angket sikap ilmiah, observasi keterampilan, observasi sikap, observasi sikap ilmiah.

\section{Teknik Analisis Data}

Hasil penelitian lapangan yang berupa data-data, kemudian diolah dan dianalisis secara kualitatif. Analisis kualitatif atau disebut juga analisis deskriptif memberi gambaran secara jelas tentang proses pelaksanaan pembelajaran dan berhubungan dengan sikap ilmiah dan prestasi belajar siswa. Penelitian ini sesuai dengan kurikulum 2013 yang hasil prestasi belajar siswa terbagi menjadi 3 aspek yaitu aspek pengetahuan, aspek sikap dan keterampilan siswa. Data hasil penelitian ini dianalisis dengan menggunakan teknik analisis Miles dan Huberman yang meliputi reduksi data, penyajian data, penarikan kesimpulan dan verifikasi (Sugiyono, 2013).

Reduksi data adalah proses dalam memilih, memusatkan perhatian pada penyederhanaan, pengabstrakan dan transformasi data hasil penelitian di lapangan. Pada intinya reduksi data yaitu merangkum, memilih dan memfokuskan hal yang pokok kemudian dicari tema serta polanya sehingga kesimpulan finalnya dapat ditarik dan diverifikasi. Data yang diperoleh dari lapangan jumlahnya cukup banyak, untuk itu data sikap ilmiah dan prestasi belajar siswa perlu direduksi. Reduksi data dapat memberikan gambaran yang lebih jelas dan mempermudah peneliti untuk melakukan langkah selanjutnya.

Penyajian data dapat dilakukan dalam bentuk uraian singkat, bagan, hubungan antar kategori, dan sebagainya sehingga data dapat 
Jurnal Inovasi Pendidikan IPA, 2 (2), 2016 - 182

Ira Maya Tri Murningsih, Mohammad Masykuri, Bakti Mulyani

terorganisasikan, tersusun dalam pola hubungan agar semakin mudah dipahami. Data interaksi sikap ilmiah dan prestasi belajar siswa baik aspek pengetahuan, sikap, maupun keterampilan yang telah direduksi kemudian disajikan dalam bentuk tabel, grafik, chart, pie, histogram, dan sejenisnya agar lebih mudah dipahami. Penyajian data akan mempermudah peneliti untuk memahami apa yang terjadi dan merencanakan langkah selanjurnya.

Penarikan kesimpulan merupakan perumusan makna dari data hasil penelitian yang ungkapkan dengan kalimat secara sistematik agar mudah dipahami dan dilakukan peninjauan secara berulang-ulang mengenai kebenaran dari kesimpulan yang berkaitan dengan judul, tujuan dan perumusan masalah yang ada serta relevansi. Data sikap ilmiah dan prestasi belajar yang telah disajikan selanjutnya disimpulkan. Penarikan kesimpulan ini merupakan upaya peneliti untuk menjabarkan hasil data yang diperoleh. Kesimpulan awal yang didapat perlu diverifikasi agar benar-benar mengahasilkan peneli-tian yang valid. Verifikasi dilakukan dengan mencari bukti-bukti pendukung yang relevan. Untuk mempermudah verifikasi dan menganalisis data dalam menjawab permasalahan yang ada, perlu diidentifikasi secara khusus disetiap siklus pembelajaran.

Pada penelitian ini digunakan teknik triangulasi data untuk memeriksa validitas data dalam penelitian. Triangulasi yang digunakan pada penelitian ini adalah triangulasi teknik pengumpulan data. Triangulasi adalah teknik pemeriksaan keabsahan data yang memanfaatkan sesuatu yang lain di luar data itu untuk keperluan pengecekan atau sebagai pembanding terhadap data itu. Triangulasi teknik pengumpulan data yang digunakan dalam penelitian ini dilakukan melalui wawancara, observasi, kajian dokumen, angket dan tes.

\section{HASIL DAN PEMBAHASAN}

Berdasarkan hasil akhir pra siklus yang meliputi wawancara dengan guru kimia yang mengampu kelas XI, observasi pada saat kegiatan pembelajaran dan tes sikap ilmiah pra siklus diperoleh hasil bahwa prestasi belajar dan sikap ilmiah siswa kelas XI MIPA 3 rendah. Oleh karena itu, perlu penanganan lebih lanjut dalam meningkatkan sikap ilmiah dan prestasi belajar siswa. Untuk mengatasi masalah tersebut diperlukan model pembelajaran yang tepat dan sesuai dengan materi kelarutan dan hasil kali kelarutan, yaitu model pembelajaran inkuiri terbimbing, sehingga penelitian ini dapat meningkatkan sikap ilmiah dan prestasi belajar kimia siswa kelas XI MIPA 3 SMA Negeri 5 Surakarta.

\section{Siklus I}

Perencanaan Tindakan

Pada tahap perencanaan tindakan meliputi penyusunan instrumen pembelajaran yang berupa persiapan silabus, penyusunan Rencana Pelaksanaan Pembelajaran (RPP) dan penyusunan instrumen penilaian aspek pengetahuan, angket penilaian diri siswa, lembar observasi sikap siswa, lembar observasi aspek keterampilan, lembar penilaian laporan keterampilan dan lembar observasi sikap ilmiah siswa.

Penelitian ini menggunakan silabus yang didapatkan dari sekolah yang didasarkan pada kurikulum 2013. Sedangkan Rencana Pelaksanaan Pembelajaran (RPP) yang digunakan ialah RPP yang dibuat oleh peneliti bersama dengan guru pengampu kimia kelas XI yang disesuaikan dengan silabus dan model pembelajaran yang akan diterapkan.

\section{Pelaksanaan Tindakan}

Pada penelitian ini digunakan kelas XI MIPA 3 yang berjumlah 30 siswa dan terdiri dari 12 siswa laki-laki dan 18 siswa perempuan. Pembelajaran dilaksanakan sesuai yang tercantum dalam Rencana Pelaksanaan Pembelajaran (RPP) yang telah disusun peneliti dan disetujui oleh guru kimia kelas XI MIPA SMA Negeri 5 Surakarta. Berdasarkan silabus dan Rencana Pelaksanaan Pembelajaran pada materi pokok kelarutan dan hasil kali kelarutan di kelas XI MIPA 3 dilakukan dalam 5 kali pertemuan atau 10 jam pelajaran, dimana dalam proses pembelajaran memerlukan 8 JP atau 4 kali pertemuan dan $2 \mathrm{JP}$ atau 1 kali pertemuan digunakan untuk evaluasi siklus I.

Pertemuan pertama siklus I membahas materi mengenai kelarutan dan hasil kali kelarutan, dan hubungan kelarutan dengan hasil kali kelarutan. Awal kegiatan pembelajaran, guru membuka pelajaran, mengabsen siswa, memberikan apresepsi, motivasi dan penyampaian tujuan pembelajaran yang dilakukan pada tiap pertemuan. Setelah kegiatan pendahuluan selesai, pembelajaran masuk pada kegiatan inti. Kegiatan inti dimulai dengan guru membagi siswa menjadi 8 kelompok yang dipilih oleh guru secara heterogen dan berdasarkan nilai UAS semester gasal. Selanjutnya guru mem- 
bagikan satu lembar diskusi setiap kelompok. Lembar diskusi tersebut disusun berdasarkan sintaks model pembelajaran inkuiri terbimbing. Setelah guru membimbing siswa melaksanakan tahap orientasi, merumuskan masalah, dan menuliskan hipotesis, setiap kelompok melakukan diskusi berdasarkan permasalahan yang ada di dalam lembar diskusi. Guru membimbing siswa untuk menemukan jawaban yang dianggap tepat sesuai dengan permasalahan yang ada. Apabila diskusi dalam setiap kelompok sudah hampir selesai guru membimbing siswa dalam menarik kesimpulan dari data yang telah diperoleh setiap kelompok, dilanjutkan dengan mempresentasikan hasil diskusi masing-masing kelompok. Pada akhir pembelajaran, guru melakukan evaluasi hasil diskusi setiap kelompok dan bersamasama siswa menarik kesimpulan pembelajaran pada pertemuan tersebut. Guru juga menyampaikan beberapa tambahan materi yang berguna untuk menambah wawasan dari siswa itu sendiri. Selanjutnya dilaksanakan posttest untuk mengetahui seberapa jauh pemahaman siswa dalam menerima materi pada pertemuan tersebut. Selain itu guru juga meminta siswa untuk mempersiapkan dan mempelajari materi pada pertemuan selanjutnya.

Pertemuan kedua, ketiga dan keempat tidak jauh berbeda dengan pertemuan pertama, hanya saja pada pertemuan kedua dan keempat tidak ada praktikum. Pada pertemuan kelima, dilaksanakan evaluasi siklus I yang meliputi penilaian aspek pengetahuan dimana siswa harus menjawab soal ulangan dan waktu yang tersisa digunakan untuk mengisi angket penilaian diri.

\section{Observasi Tindakan}

Observasi tindakan dilakukan selama pembelajaran pertemuan pertama hingga evaluasi siklus. Kegiatan pembelajaran yang berlangsung diamati dengan cermat oleh obser-ver dan guru. Keseluruhan siswa yang mengikuti pelajaran kimia dengan baik, meskipun masih terdapat beberapa siswa yang bersikap pasif. Beberapa siswa sudah mulai berani bertanya kepada guru apabila masih ada materi yang tidak dimengerti, menghormati ketika ada teman yang presentasi di depan kelas dan tidak mengeluh jika diberikan tugas oleh guru. Antusias dan rasa ingin tahu siswa di setiap pertemuan semakin meningkat, hal ini dapat dilihat dari tugas yang selalu dikerjakan oleh siswa, sebelum memulai pelajaran kimia siswa sudah sedikit mempelajari materi yang akan diterangkan oleh guru, mencoba mengerjakan soal-soal yang ada di lembar diskusi. Pada pertemuan pertama memerlukan banyak waktu dan siswa terlihat canggung serta cenderung pasif saat berdiskusi kelompok, hal ini karena sebelumnya guru belum pernah menerapkan model pembelajaran inkuiri terbimbing pada kelas XI MIPA 3. Namun di pertemuan selanjutnya siswa sudah mulai terbiasa sehingga bimbingan yang dilakukan guru semakin berkurang intensitasnya.

Hasil observasi peneliti selama pembelajaran yang dilakukan guru secara keseluruhan sudah baik dan berjalan dengan lancar. Guru telah menciptakan kondisi yang menyenangkan dan berinteraksi aktif dengan siswa, meskipun masih ada siswa yang pasif karena mungkin pada pembelajaran materi pokok kelarutan dan hasil kali kelarutan ini guru lebih menekankan pada keaktifan siswa dan memberikan kesempatan siswa untuk menemukan konsep sendiri sehingga siswa yang sudah terbiasa tergantung penjelasan guru akan merasa bosan. Namun, hal tersebut terjadi saat awal-awal pembelajaran karena selanjutnya, guru mampu memotivasi siswa agar lebih aktif saat pembelajaran. Guru membimbing siswa agar dapat menguasai materi dengan baik dan memberikan penekanan pada hal-hal yang penting dengan menggunakan model pembelajaran inkuiri terbimbing.

Hasil penilaian analisis prestasi belajar siswa pada siklus I aspek pengetahuan dapat dilihat pada Tabel 2.

Tabel 2. Ketuntasan Prestasi Belajar Aspek Pengetahuan

\begin{tabular}{ccc}
\hline Kategori & Jumlah Siswa & Ketuntasan (\%) \\
\hline Tuntas & 19 & 63 \\
Tidak Tuntas & 11 & 37 \\
\hline
\end{tabular}

Berdasarkan hasil tes pengetahuan dapat diketahui bahwa prestasi belajar pada aspek pengetahuan belum mencapai target yang ditentukan sebelumnya yaitu $75 \%$ siswa tuntas. Dilihat dari tiap indikator kompetensi, dari 8 indikator terdapar 4 indikator kompetensi yang belum mencapai target $(75 \%$ siswa menjawab benar). Adapun indikator kompetensi yang belum tercapai meliputi menjelaskan kesetimbangan dalam larutan jenuh atau larutan garam yang sukar larut, menghubungkan tetapan hasil kali kelarutan dengan tingkat kelarutan, memperkirakan terbentuknya endapan berdasarkan harga $\mathrm{K}_{\mathrm{sp}}$, dan diketahui $\mathrm{k}_{\mathrm{sp}}$ dari konsentrasi beberapa garam, siswa dapat meramalkan terbentuknya endapan. 
Jurnal Inovasi Pendidikan IPA, 2 (2), 2016 - 184

Ira Maya Tri Murningsih, Mohammad Masykuri, Bakti Mulyani

Tabel 3. Hasil Ketercapaian Prestasi Belajar Siswa Aspek Sikap Siklus I

\begin{tabular}{cc}
\hline Aspek Sikap & Ketercapaian (\%) \\
\hline Sangat Baik & 33 \\
Baik & 67 \\
Cukup & 0 \\
Kurang & 0 \\
\hline Pada siklus I ketuntasan aspek sikap men
\end{tabular}
capai $100 \%$ (siswa dikatakan tuntas dalam prestasi belajar aspek sikap apabila mendapatkan predikat minimal Baik) dan semua indikator telah memenuhi target yang ditentukan pada siklus I dan siklus II sehingga penelitian aspek sikap tidak perlu dilanjutkan pada siklus II.

Hasil yang diperoleh pada prestasi belajar aspek keterampilan tercantum dalam Tabel 4.

Tabel 4. Ketercapaian Prestasi Belajar Aspek Keterampilan Siklus I

\begin{tabular}{ccc}
\hline $\begin{array}{c}\text { Aspek } \\
\text { Keterampilan }\end{array}$ & $\begin{array}{c}\text { Target } \\
(\boldsymbol{\%})\end{array}$ & $\begin{array}{c}\text { Ketercapaian } \\
(\boldsymbol{\%})\end{array}$ \\
\hline Praktikum & \multirow{2}{*}{75} & 87 \\
Laporan & & 87 \\
\hline
\end{tabular}

Berdasarkan analisis prestasi belajar siswa aspek keterampilan siklus I terlihat bahwa pada aspek keterampilan praktikum dan pembuatan laporan telah melampaui target sehingga tidak dilanjut-kan pada siklus II. Hal tersebut menunjukkan bahwa siswa sudah terampil dalam melakukan percobaan di laboratorium dan terbiasa membuat laporan hasil praktikum.

Ketercapaian sikap ilmiah siswa pada siklus I dapat dilihat pada Tabel 6.

Tabel 5. Hasil Ketercapaian Sikap Ilmiah Siswa Siklus I

\begin{tabular}{cc}
\hline Aspek Sikap Ilmiah & Ketercapaian (\%) \\
\hline Tinggi & 60 \\
Sedang & 40 \\
Rendah & 0 \\
\hline
\end{tabular}

Target ketercapaian sikap ilmiah sebesar 75\% siswa yang berkategori sikap ilmiah tinggi, hal ini berdasarkan kesepakatan dengan guru kimia kelas XI MIPA. Pada siklus I ketercapaian sikap ilmiah sebesar $60 \%$ dan terdapat 1 indikator yang belum memenuhi target yaitu pada indikator sikap ingin menemukan sesuatu yang baru. Hasil sikap ilmiah siklus I disimpulkan bahwa aspek sikap ilmiah belum mencapai target yang ditetapkan sehingga perlu dilanjutkan ke siklus II.

\section{Refleksi Tindakan}

Pembelajaran siklus I bertujuan agar siswa dapat menguasai semua indikator kompe- tensi pada materi pokok kelarutan dan hasil kali kelarutan yang dilaksanakan sebanyak 5 kali pertemuan (10 JP). Pelaksanaan tindakan siklus I dari pertemuan pertama sampai pertemuan keempat dilakukan pengambilan data berupa observasi sikap dan sikap ilmiah oleh observer. Pada pertemuan keempat dilakukan pengambilan data berupa observasi keterampilan siswa dalam melaksanakan percobaan di laboratorium dan pertemuan ke lima digunakan untuk pengambilan data yang meliputi tes aspek pengetahuan, angket sikap dan angket sikap ilmiah.

Kegiatan pembelajaran yang dimulai dari pertemuan pertama sampai pertemuan keempat sudah berjalan dengan baik dimana banyak siswa yang antusias dalam menerima pelajaran yang dilihat dari siswa mulai memperhatikan pelajaran dengan tenang, tugas dikerjakan dengan teliti dan tepat waktu, mencoba sendiri mengerjakan soal-soal yang ada di buku tanpa disuruh, aktif bertanya ke guru maupun teman lainnya jika ada materi yang belum dimengerti dan berani untuk mengerjakan soal di depan kelas tanpa harus ditunjuk terlebih dahulu oleh guru. Kegiatan diskusi dalam kelompok berjalan dengan baik, meskipun pada pertemuan pertama siswa masih pasif dan belum menunjukkan keaktifan kegiatan kelompok. Namun pada pertemuan selanjutnya terlihat siswa dalam satu kelompok saling menyampaikan gagasan selama diskusi berlangsung, berebutan untuk maju mempresentasikan hasil diskusi kelompok masing-masing dan waktu presentasi mulai ada kegiatan bertanya, menyanggah maupun menambahi jika masih ada pernyataan teman yang salah. Suasana pembelajaran pada materi pokok kelarutan dan hasil kali kelarutan sudah mengarah pada pembelajaran yang berpusat kepada siswa dan guru hanya sebagai fasilitator dengan sedikit bimbingan tetapi setiap pertemuan bimbingan guru semakin berkurang intensitasnya.

Ketercapaian sikap ilmiah dan prestasi belajar siswa yang meliputi aspek pengetahuan, sikap dan keterampilan pada siklus I dapat dilihat pada Tabel 6 . 
Jurnal Inovasi Pendidikan IPA, 2 (2), 2016 - 185

Ira Maya Tri Murningsih, Mohammad Masykuri, Bakti Mulyani

Tabel 6. Ketercapaian Target Siklus I Materi Pokok Kelarutan Dan Hasil Kali Kelarutan Siswa Kelas XI MIPA 3 SMA Negeri 5 Surakarta.

\begin{tabular}{|c|c|c|c|}
\hline $\begin{array}{c}\text { Aspek yang } \\
\text { dinilai }\end{array}$ & $\begin{array}{c}\text { Target } \\
(\%)\end{array}$ & $\begin{array}{c}\text { Ketercapaian } \\
(\%)\end{array}$ & Kriteria \\
\hline Sikap ilmiah & & 60 & $\begin{array}{c}\text { Belum } \\
\text { Tercapai } \\
\text { Belum }\end{array}$ \\
\hline Pengetahuan & 75 & 63 & $\begin{array}{c}\text { Tercapa } \\
\text { i }\end{array}$ \\
\hline $\begin{array}{c}\text { Sikap } \\
\text { Keteramnilan }\end{array}$ & & 100 & Tercapai \\
\hline
\end{tabular}

Berdasarkan Tabel 6 dapat diketahui bahwa dari keempat aspek yang dinilai selama pembelajaran siklus I yaitu sikap ilmiah, pengetahuan, sikap dan keterampilan terdapat dua aspek yang belum mencapai target pada siklus I. Sikap ilmiah belum mencapai target dan ada 1 indikator yang belum tercapai, sedangkan aspek pengetahuan belum mencapai target dan 3 indikator kompetensi aspek pengetahuan yang belum dikuasai siswa yaitu menjelaskan kesetimbangan dalam larutan jenuh atau larutan garam yang sukar larut, menghubungkan tetapan hasil kali kelarutan dengan tingkat kelarutan, memperkirakan terbentuknya endapan berdasarkan harga $\mathrm{K}_{\mathrm{sp}}$, dan diketahui ksp dari konsentrasi beberapa garam, siswa dapat meramalkan terbentuknya endapan. Oleh karena itu, perlu adanya tindakan pada siklus II sehingga ketercapaian seluruh indikator dapat tuntas seluruhnya dan kekurangan yang ada pada siklus I diperbaiki pada siklus II, hal ini sesuai dengan tujuan dari refleksi siklus I yaitu untuk mengetahui kekurangan yang terdapat selama proses pembelajaran pada siklus I dan meningkatkan ketercapaian target yang telah dicapai pada siklus I. Sedangkan, pembelajaran siklus II dilakukan untuk memperbaiki proses pembelajaran materi kelarutan dan hasil kali kelarutan dengan model inkuiri terbimbing. Perbaikan yang direncanakan untuk pembelajaran siklus II yaitu meyusun Rencana Pelaksanaan Pembelajaran (RPP) yang lebih difokuskan pada indikator kompetensi yang belum dikuasai oleh siswa.

\section{Siklus II}

Perencanaan Tindakan

Perbaikan yang direncanakan untuk pembelajaran siklus II yaitu menyusun Rencana Pelaksanaan Pembelajaran yang lebih difokuskan pada indikator kompetensi yang belum dikuasai oleh siswa. Pembagian kelompok pada pelaksanaan proses pembelajaran di siklus II masih sama dengan pembelajaran pada siklus I. Tindakan perbaikan dari siklus I adalah saat pembelajaran di siklus II, guru mendatangi tiap kelompok untuk dapat memantau letak kekurangan siswa dalam memahami materi dan memberikan kesempatan atau memotivasi kepada siswa yang kurang percaya diri dalam bertanya, menjawab soal di depan kelas serta mempresentasikan hasil diskusi kelompok, serta guru lebih memfokuskan perhatiannya ke siswa yang mendapatkan nilai dibawah KKM pada evaluasi siklus I.

\section{Pelaksanaan Tindakan}

Pembelajaran siklus II dilaksanakan dalam 2 kali pertemuan dengan alokasi 1 kali pertemuan untuk proses pembelajaran dan 1 kali pertemuan untuk evaluasi siklus II. Pertemuan pertama membahas materi yang belum dikuasai siswa berdasarkan refleksi pada siklus I. Pada siklus II guru juga menerapkan model pembelajaran inkuiri terbimbing. Pada pembelajaran siklus II diawali dengan apersepsi yang berupa pertanyaan yang berkaitan dengan materi sebelumnya yang telah dipelajari. Tahap selanjutnya guru memberikan orientasi mengenai model pembelajaran inkuiri terbimbing dan tujuan pembelajaran pada pertemuan tersebut. Guru juga memberikan motivasi kepada siswa mengenai manfaat mempelajari materi kelarutan dan hasil kali kelarutan.

Pada kegiatan inti, guru membagikan lembar diskusi kepada masing-masing kelompok. Guru memberikan permasalahan kepada siswa berdasarkan lembar diskusi, kemudian membimbing siswa merumuskan masalah dan hipotesis. Dalam kegiatan diskusi ini guru berperan sebagai fasilitator yang mengarahkan siswanya untuk menyelesaikan permasalahan dan membantu siswa yang mengalami kesulitan. Selain itu guru keliling ke kelompok untuk memantau jalannya diskusi siswa. Apabila diskusi sudah selesai, sintaks model pembelajaran inkuiri terbimbing selanjutnya adalah menguji hipotesis yaitu guru membimbing siswa untuk menentukan jawaban yang dianggap tepat. Setelah itu setiap kelompok mempresentasikan hasil diskusinya ke depan kelas. Kemudian siswa dengan bimbingan guru menarik kesimpulan pembelajaran pada pertemuan tersebut sehingga siswa semakin paham.

Evaluasi aspek pengetahuan dan sikap ilmiah pada siklus II ini dilaksanakan pada pertemuan kedua. Tes aspek pengetahuan terdiri dari 25 soal objektif dengan alokasi waktu 90 
menit. Soal tes pengetahuan yang digunakan berbeda dengan dengan siklus I tetapi indikator kompetensinya sama. Untuk sikap ilmiah siswa digunakan angket penilaian diri yang sama dengan siklus I yaitu berjumlah 30 butir soal.

\section{Observasi Tindakan}

Pembelajaran pada siklus II menurut hasil observasi siswa terlihat lebih antusias lagi dalam mengikuti pelajaran dibandingkan ketika pembelajaran di siklus I. Siswa lebih banyak mengemukakan gagasan-gagasan dan aktif dalam proses pembelajaran. Pada siklus II siswa belajar dengan kelompok yang sama dengan siklus I karena agar siswa tidak perlu lagi menyesuaikan diri dalam kelompok yang pastinya memiliki karakter dan pemikiran yang berbeda-beda, sehingga dengan kelompok yang sama akan membuat siswa nyaman belajar dan berpartisipasi aktif di dalam pembelajaran maupun diskusi. Di siklus II ini juga terlihat siswa yang sudah paham dengan materi kelarutan dan hasil kali kelarutan mengajari temannya yang belum paham dalam satu kelompok. Guru dalam proses pembelajaran di siklus II ini berperan sebagai fasilitator dalam kegiatan diskusi ataupun presentasi dan membenarkan materi apabila siswa menyampaikan konsep yang salah. Guru juga memberikan penekanan materi yang penting dan harus dipahami siswa. Analisis hasil prestasi belajar siswa aspek pengetahuan siklus II dapat dilihat pada Tabel 7.

Tabel 7. Ketuntasan Prestasi Belajar Aspek Pengetahuan Siklus II

\begin{tabular}{ccc}
\hline Kategori & Jumlah Siswa & Ketuntasan (\%) \\
\hline Tuntas & 28 & 93 \\
Tidak Tuntas & 2 & 7 \\
\hline
\end{tabular}

Hasil ini sudah memenuhi target ketuntasan dan semua indikator kompetensi telah mencapai target penelitian.Hasil sikap ilmiah pada siklus II disajikan pada Tabel 8 .

Tabel 8. Hasil Ketercapaian Sikap Ilmiah Siswa Siklus II

\begin{tabular}{cc}
\hline Aspek Sikap Ilmiah & Ketercapaian (\%) \\
\hline Tinggi & 93 \\
Sedang & 7 \\
Rendah & 0
\end{tabular}

Hasil aspek sikap ilmiah siklus II disimpulkan bahwa aspek sikap ilmiah siswa sudah tercapai pada siklus II karena sudah mencapai target sebesar $75 \%$. Ketercapaian siklus II mencapai $93 \%$ atau 28 siswa memiliki sikap ilmiah berkategori tinggi. Indikator kompetensi sikap ilmiah yang berupa rasa ingin tahu, sikap menemukan sesuatu yang baru, tekun dan tidak mudah putus asa, cermat dan teliti, menyampaikan ide, menghargai dan menghormati orang lain dan kritis telah mencapai target.

\section{Refleksi Tindakan}

Berdasarkan data yang diperoleh pada siklus II, terlihat semua aspek meliputi aspek pengetahuan dan sikap ilmiah mengalami peningkatan capaian dan sudah melampaui target sehingga penelitian di akhiri pada siklus II.

\section{Perbandingan Tindakan Antar Siklus}

Penerapan model pembelajaran inkuiri terbimbing (guided inquiry) pada materi pokok kelarutan dan hasil kali kelarutan dilaksanakan dalam dua siklus. Tujuan dibandingkannya hasil tindakan antar siklus digunakan untuk mengetahui peningkatan yang terjadi selama pelaksanaan tindakan siklus I dan siklus II.

\section{Sikap Ilmiah Siswa}

Aspek yang dinilai dalam penilaian sikap ilmiah siswa meliputi rasa ingin tahu, sikap ingin menemukan sesuatu yang baru, tekun dan tidak mudah putus asa, teliti, menyampaikan ide atau pendapat, menghormati dan menghargai orang lain, kritis. Ketuntasan siswa sebesar $60 \%$ atau sebanyak 18 siswa. Hal ini belum memenuhi target yang diharapkan yaitu $75 \%$. Dari 30 siswa di kelas XI MIPA 3, siswa dengan kategori tinggi sebesar $60 \%$, siswa dengan kategori sedang sebesar $40 \%$ dan siswa yang berkategori rendah sebesar $0 \%$. Sedangkan hasil analisis penilaian sikap ilmiah dalam pembelajaran siklus II, ketuntasan siswa sebesar $93 \%$ atau sebanyak 28 siswa.

Peningkatan ketuntasan sikap ilmiah sejalan dengan teori Gagne. Gagne mengemukakan bahwa belajar bertujuan untuk mengubah sikap yang negatif menjadi positif yang dalam hal ini sikap positif tersebut adalah sikap ilmiah. Belajar menurut gagne sebagai perubahan tingkah laku individu sebagai hasil pengalaman yang berinteraksi dengan lingkungan. Dalam model pembelajaran inkuiri terbimbing menuntut siswa memiliki sikap ilmiah yang akan mempengaruhi perubahan perilaku siswa.

Data sikap ilmiah pada siklus I dan II dapat dilihat pada Tabel 9. Berdasarkan data, jumlah siswa yang memiliki sikap ilmiah tinggi dari siklus I meningkat di siklus II. 
Jurnal Inovasi Pendidikan IPA, 2 (2), 2016 - 187

Ira Maya Tri Murningsih, Mohammad Masykuri, Bakti Mulyani

Tabel 9. Ketuntasan Sikap Ilmiah Siswa Pada Siklus I dan Siklus II

\begin{tabular}{|c|c|c|c|}
\hline Siklus I & & Siklus II & \\
\hline $\begin{array}{c}\text { Ketercapaian } \\
(\%)\end{array}$ & Kriteria & $\begin{array}{c}\text { Ketercapaian } \\
(\%)\end{array}$ & Kriteria \\
\hline 60 & $\begin{array}{l}\text { Belum } \\
\text { Tuntas }\end{array}$ & 93 & Tuntas \\
\hline
\end{tabular}

Diagram batang yang menggambarkan perbandingan jumlah peserta didik tiap kriteria sikap ilmiah pada siklus I dan II dalam persentase disajikan pada Gambar 1.

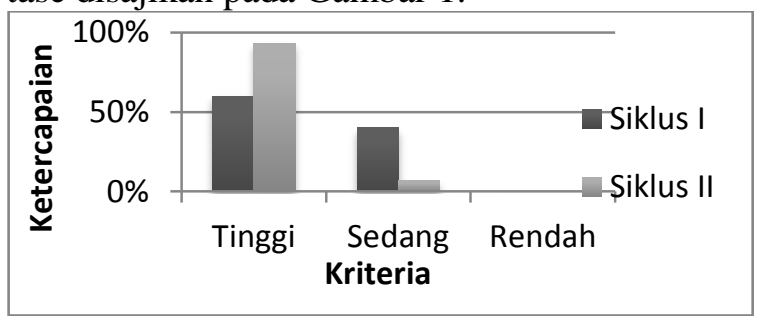

Gambar 1. Peningkatan Sikap ilmiah Siswa Pada Siklus I dan Siklus II

Prestasi Belajar Aspek Pengetahuan

Evaluasi aspek pengetahuan berjumlah 25 butir soal pada siklus I dan siklus II dalam 90 menit waktu pengerjaan yang terdiri dari 8 indikator kompetensi. Hasil analisis aspek pengetahuan siklus I menyatakan bahwa terdapat 19 dari 30 siswa di kelas XI MIPA 3 telah mencapai ketuntasan belajar sebesar 63\% dan 11 siswa atau $37 \%$ belum mencapai batas ketuntasan. Ketercapaian target aspek pengeta-huan tiap indikator kompetensi terdapat 4 dari 8 indikator yang belum mencapai target $75 \%$ yang ditetapkan sehingga harus dilanjukan ke siklus II. Indikator-indikator yang belum tercapai, yaitu menjelaskan kesetimbangan dalam larutan jenuh atau larutan garam yang sukar larut, menghubungkan tetapan hasil kali kelarutan dengan tingkat kelarutan, memperkirakan terbentuknya endapan berdasarkan harga $\mathrm{K}_{\mathrm{sp}}$, dan diketahui ksp dari konsentrasi beberapa garam, siswa dapat meramalkan terbentuknya endapan. Ketercapaian hasil tes pengetahuan siklus II menyatakan bahwa jumlah siswa yang telah tuntas sebesar $93 \%$ atau 28 siswa, sedangkan siswa yang belum tuntas sebanyak 2 siswa atau $7 \%$. Hasil pada siklus II sudah melampaui target $75 \%$. Ketuntasan siswa maka prestasi belajar aspek pengetahuan dapat diakhiri. Peningkatan ketuntasan siklus I dan siklus II untuk prestasi belajar aspek pengetahuan disajikan pada Gambar 2.

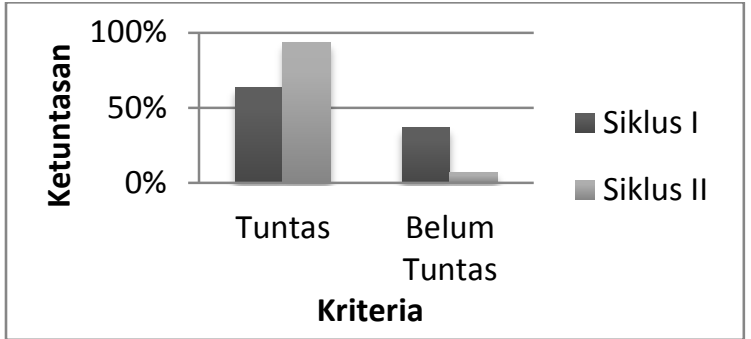

Gambar 2. Diagram Ketuntasan Prestasi Belajar Aspek Pengetahuan Siklus I dan Siklus II

Berdasarkan pada diagram batang dalam bentuk Gambar 2. menyatakan bahwa ketuntasan siswa pada siklus II lebih tinggi dibandingkan dengan siklus I. Berdasarkan data tersebut dapat diketahui bahwa terdapat peningkatan pesentase siswa yang tuntas dari siklus I dan siklus II sebesar $30 \%$ yang dikarenakan pada model pembelajaran inkuiri terbimbing siswa dibimbing untuk menemukan konsep dari pengamatan sehingga siswa lebih mudah mengabstraksikan ke dalam pikiran, hal ini sejalan dengan teori Piaget. Penelitian ini juga sejalan dengan teori Ausubel yang mana siswa dituntut aktif dalam penemuan konsep dengan mengalami sendiri dalam mendapatkan konsep-konsep yang dipelajari, sehingga konsep yang didapat siswa tersebut akan dapat bertahan lebih lama dan akan menjadi lebih bermakna serta sesuai dengan teori Bruner yang meng-hendaki siswa untuk belajar memecahkan permasalahan yang dimunculkan oleh guru dan guru berusaha memberi solusi bagaimana mengarahkan siswa berperan aktif dalam menemukan konsep sendiri.

\section{Prestasi Belajar Aspek Sikap}

Aspek sikap yang dinilai adalah sikap spiritual dan sikap sosial. Sikap sosial meliputi disiplin, tanggung jawab, kerja sama, sopan santun dan jujur. Sikap kerjasama siswa mencapai $100 \%$ dan berdasarkan observasi terlihat meningkat dari sebelum tindakan hingga pada saat penerapan model pembelajaran inkuiri terbimbing. Sikap kerjasama mengalami peningkatan karena dalam proses pembelajaran inkuiri terbimbing siswa dilatih belajar menemukan pengetahuannya sendiri melalui diskusi pada kelompoknya. Dalam proses belajarnya, siswa berinteraksi dengan teman dan guru. Hal ini sesuai dengan teori belajar Vigotsky dalam Trianto (2007) yang memiliki tiga prinsip kunci, yaitu penekanan pada aspek sosial pembelajaran, zone of proximal development (ZPD) dan scaffolding. Adanya diskusi dalam kelompok, 
Jurnal Inovasi Pendidikan IPA, 2 (2), 2016 - 188

Ira Maya Tri Murningsih, Mohammad Masykuri, Bakti Mulyani

menjadikan siswa harus berinteraksi dengan teman satu kelompoknya sehingga terjadi kerja sama antara siswa dalam kelompok tersebut.

Sikap tanggung jawab juga mencapai $100 \%$ dan berdasarkan observasi meningkat seiring dengan meningkatnya kerjasama siswa. Adanya peningkatan sikap tanggungjawab ini dikarenakan dalam pelaksanaan pembelajaran inkuiri terbimbing terdapat pembagian peran siswa dalam kelompok.

Ketuntasan hasil analisis penilaian aspek sikap dalam pembelajaran siklus I sudah sesuai dengan target yang direncanakan dengan ketuntasannya sebesar $100 \%$. Penilaian prestasi belajar aspek sikap dilakukan hanya satu siklus karena telah mencapai target ketuntasan yaitu 75\% siswa berkategori minimal baik dan ketercapaian tiap indikator juga sudah mencapai target. Hal ini dikarenakan cara menghitung nilai pada aspek sikap menurut kurikulum 2013 adalah menggunakan nilai modus, sangat dimungkankan diperoleh hasil capaian mencapai ketuntasan $100 \%$

\section{Prestasi Belajar Aspek Keterampilan}

Pada kurikulum 2013 selain aspek pengetahuan dan aspek sikap, prestasi belajar juga dinilai dari aspek keterampilan. Hasil analisis aspek keterampilan siswa sebesar 100\% telah melampaui target. Hal tersebut menunjuk-kan bahwa siswa sudah terampil dalam melakukan percobaan di laboratorium dan terbiasa membuat laporan hasil praktikum. Selain itu, dikarenakan cara menghitung nilai pada aspek ini menurut kurikulum 2013 adalag dengan menggunakan nilai optiumum yang dicapai. Dengan sistem penilaian menggunakan nilai optimum, sangat dimungkinkan akan diperoleh hasil capaian mencapai ketuntasan optimum sebesar $100 \%$.

Hasil akhir penilaian aspek keterampilan dapat diketahui ketuntasan siswa dengan nilai $\mathrm{A}$ sebanyak $13 \%$, siswa dengan nilai A- sebanyak $37 \%$ dan siswa dengan nilai B+ sebanyak 50\%. Seperti halnya sama dengan aspek sikap, keterampilan siswa dilakukan hanya satu siklus yaitu pada pertemuan ketiga siklus I karena sudah melebihi target ketuntasan siswa.

Hasil penelitian ini menunjukkan bahwa, penerapan model pembelajaran inkuiri terbimbing (guided inquiry) dapat meningkatkan sikap ilmiah dan prestasi belajar siswa pada materi kelarutan dan hasil kali kelarutan kelas XI MIPA 3 SMA Negeri 5 Surakarta Tahun Pelajaran 2015/2016.

\section{SIMPULAN DAN SARAN}

\section{Simpulan}

Berdasarkan hasil penelitian yang telah dilaksanakan, maka dapat diperoleh kesimpulan: (1) Penerapan model pembelajaran inkuri terbimbing dapat meningkatkan sikap ilmiah siswa pada materi pokok kelarutan dan hasil kali kelarutan siswa kelas XI MIPA 3 SMA Negeri 5 Surakarta tahun pelajaran 2015/2016, (2) Penerapan model pembelajaran inkuri terbimbing dapat meningkatkan prestasi belajar siswa pada materi pokok kelarutan dan hasil kali kelarutan siswa kelas XI MIPA 3 SMA Negeri 5 Surakarta tahun pelajaran 2015/2016.

Ketercapaian sikap ilmiah pada siklus I mencapai $60 \%$ dan meningkat di siklus II menjadi $93 \%$. Aspek pengetahuan di siklus I ketuntasannya sebe-sar $63 \%$ dan meningkat di siklus II menjadi 93\%. Aspek sikap dan kete-rampilan siswa telah tuntas pada siklus I dengan ketercapaian sebesar $100 \%$ dan semua indikator juga memenuhi target.

\section{Saran}

Dalam pembelajaran kimia, guru dapat menyajikan pembelajaran pada materi pokok kelarutan dan hasil kali kelarutan menggunakan model pembelajaran inkuiri terbimbing, sehingga dapat meningkatkan kompetensi pengetahuan siswa.

Peneliti lain yang akan melakukan penelitian sejenis sedapat mungkin menganalisis kembali terlebih dahulu perangkat pembelajaran yang telah dibuat untuk disesuaikan dalam penggunaannya, terutama dalam hal alokasi waktu, fasilitas pendukung dan karakteristik peserta didik yang ada di tempat penelitian tersebut, serta hasil penelitian ini dapat digunakan sebagai acuan penelitian selanjutnya dengan mengungkapkan aspek-aspek yang belum disampaikan dan dikembangkan.

\section{DAFTAR PUSTAKA}

Arikunto, S. (1992). Prosedur penelitian suatu pendekatan pratik. Jakarta: PT Rineka Cipta.

Baharudin. (1982). Peranan kemampuan dasar intelektual, sikap dan pemahaman dalam fisika terhadap kemampuan siswa di Sulawesi Selatan membangun model analog dan model mental, Desertasi Doktor FSP FKIP, IKIP Bandung, tidak diterbitkan. 
Jurnal Inovasi Pendidikan IPA, 2 (2), 2016 - 189

Ira Maya Tri Murningsih, Mohammad Masykuri, Bakti Mulyani

https://shintanvyp.wordpress.com/tag/sika p-ilmiah/2014. akses 17 Februari 2016.

Basrowi \& Suwandi. (2008). Memahami penelitian kualitatif. Jakarta: Rineka Cipta.

Daryanto \& Rahardjo, M. (2012). Model pembelajaran inovatif. Yogyakarta: Penerbit Gava Media.

Dewi, N., Dantes, N., \& Sadia. I. (2013). Pengaruh model pembelajaran inkuiri terbimbing terhadap sikap ilmiah dan hasil belajar IPA. Journal Program Pascasarjana Universitas Pendidikan Ganesha, Volume 3.

Fatonah, S., \& Prasetyo, Z. K. (2014). Pembelajaran sains. Yogyakarta: Penerbit Ombak.

Gulo, W. (2002). Strategi belajar-mengajar. Jakarta: Grasindo

Jack, G. (2013). Concept mapping and guided inquiry as effective techniques for teaching difficult concepts in chemistry: effect on students' academic achievement. Journal of Education and Practice, 4 (5), 9-15.

Kasbolah, K. (2001). Penelitian tindakan kelas. Malang: Universitas Negeri Malang.

Mulyasa, E. (2007). Kurikulum tingkat satuan pendidikan. Bandung: PT Remaja Rosdakarya.

Peraturan Menteri Pendidikan dan Kebudayaan. (2013). Lampiran peraturan menteri pendidikan dan kebudayaan nomor 69 Tahun 2013 tentang kerangka dasar dan struktur kurikulum sekolah menengah atas/madrasah aliyah. Jakarta: Kemendikbud

Pertiwi, D., Eny \& Husna. (2013). Improving students' scientific attitude towards experiment method with inquiry approach on the rmochemistry subject in eleventh grade science students of SMAN 3 Sanggau. Jurnal Penelitian FKIP Kimia Untan. 2013 (1), 1-13.

Sugiyono. (2013). Metode penelitian pendidikan pendekatan kuantitatif, kualitatif, dan R \& D. Bandung: Alfabeta

Suyadi. (2012). Panduan penelitian tindakan kelas. Yogyakarta: DIVA Press.

Utami, W., Dasna, I., \& Sulistina, O. (2013). Pengaruh penerapah model pembelajaran inkuiri terbimbing terhadap hasil belajar dan keterampilan proses sains siswa pada materi kelarutan dan hasil kali kelarutan. Jurnal Penelitian Pendidikan FKIP Universitas Negeri Malang, 2013 (1).

Villagonzalo, E.C. (2014). Process oriented guided inquiry learning: an effective approach in enhancing student' academic perfomance. Presented at the DLSU Research Congress 2014. Philippines: De La Salle University, Manila.

Vlassi, M. \& Karaliota, A. (2013). The comparison between guided inquiry and traditional teaching method. A case study for the teaching of the structure of matter to 8th grade Greek students. Procedia: Social and Behavioral Sciences, 2013 (93), 494-497. 